\title{
Brain Stem Intraparenchymal Clear Cell Meningioma
}

National Cancer Institute

\section{Source}

National Cancer Institute. Brain Stem Intraparenchymal Clear Cell Meningioma. NCI

Thesaurus. Code C5295.

A morphologic variant of meningioma arising from the brain stem. It is characterized by the presence of clear glycogen-rich polygonal cells. 